\title{
SECULARIZAÇÃO, LAICIDADE E COSMOVISÕES EM CONFLITO: O ESPAÇO DA RELIGIÃO NA ESFERA PÚBLICA
}

\section{Adriana Reis de Albuquerque ${ }^{1}$}

Desde o princípio, a voz de Deus que conclama à vida se comunica no interior de um universo moralmente sensível. ${ }^{2}$

\section{Resumo}

O presente artigo tem por objetivo discutir o espaço da religião na esfera pública, dentro de um Estado de direito de viés democrático. O texto evidencia como o desenvolvimento do Estado constitucional de cunho liberal influenciou a superveniência de uma concepção restritiva do papel da religião na esfera pública, criando um conceito de tolerância enquanto "indiferença”, a partir de uma absoluta dissociação entre o público e o privado. Correlaciona o fortalecimento da visão que afasta o elemento religioso do debate público e da esfera institucional do Estado com a cosmovisão pós-moderna. A partir da distinção entre Estado e sociedade, defende a ineficácia do conceito de tolerância liberal para lidar com uma sociedade que deve ser caracterizada como "pós-secular", a demandar que o Estado dialogue com o elemento religioso. A partir do referencial teórico de Jurgen Habermas e Michael Sandel, o artigo defende não só a possibilidade, como a efetiva necessidade de que, cumpridos determinados pressupostos epistemológicos, o argumento religioso seja incorporado ao debate político e mesmo institucional, mediante a substituição da ideia de neutralidade como "indiferença" por neutralidade como "inclusão", possibilitando o surgimento de um cenário social e jurídico de maior comprometimento com as divergências morais e maior densidade democrática.

\footnotetext{
${ }^{1}$ Doutoranda em Direito na Universidade Federal do Ceará. Mestre em Direito pela UFPE. Especialista em Direito Tributário pelo IBET. Especialista em Integração Econômica e Direito Internacional Fiscal pela FGV/ESAF. Especialista em Administração Pública pela FGV. Procuradora da Fazenda Nacional. E-mail: adri_london@hotmail.com

${ }^{2}$ HABERMAS, Jurgen. Fé e Saber. São Paulo: Editora Unesp, 2013, p. 25-26
} 
Palavras-chave: Religião. Secularização. Laicidade. Esfera pública. Democracia.

\section{INTRODUÇÃO}

No dia 13 de abril de 2012, o Supremo Tribunal Federal concluiu o julgamento da Ação de Descumprimento de Direito Fundamental no 54 , no bojo da qual a Confederação Nacional dos Trabalhadores na Saúde requereu ao Supremo Tribunal a declaração de inconstitucionalidade, com eficácia para todos e efeito vinculante, da interpretação dos artigos 124, 126 e 128, incisos I e II, do Código Penal, nas hipóteses de gestação de fetos anencéfalos.

No bojo da ADPF, não se requereu a declaração de inconstitucionalidade em abstrato dos dispositivos que tipificam o crime de aborto no Brasil, mas tão somente sua interpretação conforme à Constituição - à luz do preceito que garante o Estado laico, bem como das garantias dos direitos à vida, dignidade da pessoa humana, privacidade e saúde - de modo a se permitir às gestantes de fetos anencéfalos a interrupção da gravidez, sem necessidade de prévia autorização judicial caso a caso.

Em seu voto condutor, o Ministro Marco Aurélio, relator desta ADPF, estabeleceu que, a despeito da menção a Deus no preâmbulo da Constituição Federal de 1988, o STF já teria assentado, quando do julgamento da Ação Direta de Inconstitucionalidade no 2.076/AC, de relatoria do Ministro Carlos Velloso, a inexistência de força normativa desta parte do texto.

Como consequência disto, sustentou que "Deuses e césares têm espaços apartados. O Estado não é religioso, tampouco é ateu. O Estado é simplesmente neutro" (STF, 2018, p. 39).

O argumento da laicidade do Estado - basilador de todo o voto - levou o Ministro a concluir que o Brasil "não é um Estado religioso tolerante com minorias religiosas e com ateus, mas um Estado secular tolerante com as religióes, o que o impede de transmitir a mensagem de que apoia ou reprova qualquer delas" (STF, 2018, p. 40), razão pela qual "concepções morais religiosas, quer unânimes, quer majoritárias, quer minoritárias, não podem guiar as decisões estatais, devendo ficar circunscritas à esfera privada” (STF, 2018, p. 42).

A ideia de que não cabe à religião intervir na esfera pública, devendo existir uma absoluta dissociação entre a esfera privada do indivíduo e sua atuação na esfera pública enquanto agente influenciador e definidor de políticas públicas, também apareceu quando do julgamento da Ação Direta de Inconstitucionalidade nº 3.510, na qual se debateu a possibilidade de realização de pesquisas científicas com células-tronco embrionárias.

No julgamento daquela ADIN, o Ministro Celso de Mello Filho defendeu, referindo-se ao Direito, que vol.12, no. 01, Rio de Janeiro, 2019.pp.77-99 
cabe às autoridades que o aplicam "despojar-se de pré-compreensões em matéria confessional, em ordem a não fazer repercutir sobre o processo de poder, quando em exercícios de suas funções, qualquer que seja o domínio de sua incidência, as suas próprias convicções religiosas"3.

Os julgamentos proferidos na ADPF no 54 e da ADIN no 3.510 evidenciam, no Brasil, uma mesma tendência já constatada no sistema legal norte-americano, no sentido de entender que o recurso ao elemento religioso desqualifica o âmbito do jurídico ${ }^{4}$, de modo a se sustentar uma total e absoluta impossibilidade de participação do elemento religioso na esfera pública.

Sob a perspectiva da Constituição política do Estado, a absoluta dissociação entre o jurídico e o religioso remonta à construção do Estado democrático de Direito em sua feição liberal, inicialmente erigido ainda dentro do paradigma da modernidade.

No Estado Constitucional de Direito de cunho liberal, o que se verifica é a existência de um Estado que diferencia, com absoluta rigidez, as esferas do público e do privado, a impedir, no bojo da esfera pública, a partir da adoção da característica da laicidade como "neutralidade", a inserção de argumentos de índole moral e, especialmente, religiosos.

Essa visão dissociativa entre o religioso e o jurídico é ainda reforçada, sob o ponto de vista global, pelo desenvolvimento e consolidação da cosmovisão pós-moderna, "que encara a moralidade como uma invenção humana" (COLSON; PEARCEY, 2006, p. 204) incapaz de funcionar como o elemento justificador da esfera pública, que deve encontrar sua legitimidade no respeito a requisitos de natureza formal.

Luiz Felipe Pondé destaca, dentre tantas características da cosmovisão pós-moderna, o elemento do relativismo.

Neste sentido, Segundo Pondé (2011)

O mal-estar do pós-moderno é seguido da angústia de ser livre, (...) Finalmente eu

\footnotetext{
3 BRASIL. Ação Direta de Inconstitucionalidade no 3510. Relator Ministro Ayres Brito. DJ: 29/05/2008. Julgado: 06/06/2018. Fonte STF: http://www.stf.jus.br/portal/geral/verPdfPaginado.asp?id=611723\&tipo=AC\&descricao=Inteiro\%20Teor\%20 ADI\%20/\%203510

${ }^{4}$ Em "O cristão na Cultura de hoje", Charles Colson e Nancy Pearcey demonstram, a partir de diversos casos concretos, como o Sistema Jurídico americano caminhou de um cenário no qual, de início, as Cortes desvincularam a interpretação jurídica das normas em vigor da existência de uma lei superior, de caráter religioso, moral, ético, para culminar com a defesa da concepção de que o caráter religioso por trás de uma lei serve para desqualificá-la. Nesse sentido, evidenciam, dentre outros exemplos, caso no qual a Suprema Corte do Estado da Louisiana, em 1987, anulou um Estatuto que determinava, com base na liberdade religiosa, o estudo do criacionismo em conjunto com o estudo do evolucionismo, sob o argumento de que "o objetivo secular reinvicado pela legislatura (ou seja, a liberdade acadêmica) era um logro, encobrindo o que realmente era uma tentativa de promover a religião bíblica" (2006, p. 202).

5 PONDÉ, Luiz Felipe. Invenção do Contemporâneo: Diagnóstico de Zygmunt Bauman para a PósModernidade - In Café Filosófico. Campinas: CPFL Cultura, 2011. Disponível em < https://www.youtube.com/watch?v=qx-tRVyMphk >. Acesso em: 26 jun. 2016.
} 
consegui ser livre porque vivo numa democracia, larguei as tradições, não sou obrigado a seguir muita coisa, (... ) mas é justamente esta liberdade que nos atormenta, já que parece que não queríamos ser tão livres assim.

Nas palavras de Dinesh D'Souza (2008, p. 75), "hoje, os Tribunais interpretam de modo errôneo a separação entre Igreja e Estado, no sentido de negar à religião seu espaço na arena pública ou impedir que a moralidade derivada da religião molde nossas leis".

Este artigo parte da premissa de que a adoção de um Estado democrático de Direito, caracterizado pela laicidade, não impede a participação do argumento religioso na esfera pública, mas ao contrário, o exige.

Adotada esta premissa, desenvolvida ao longo do texto, o foco de análise deixa de ser a (im) possibilidade de participação do religioso no espaço público para se voltar aos mecanismos, procedimentos e limites a partir dos quais essa intervenção deve ocorrer.

Em síntese, questiona-se "como a separação constitucional entre Estado e Igreja infuencia o papel que as tradições religiosas, comunidades e organizações estão autorizadas a desempenhar na esfera pública e no Estado em geral" (HABERMAS, 2006, p. 4).

Para atingir esse objetivo, o artigo analisa o conceito de Estado constitucional democrático de direito com o propósito de demonstrar como seu desenvolvimento, em uma feição liberal, produziu uma concepção demasiadamente restritiva acerca da possibilidade de participação do argumento moral - e dentro dele do religioso - na esfera pública.

Em seguida, evidencia-se o conceito de "cosmovisão" e os principais elementos da cosmovisão pósmoderna, de modo a estabelecer como se dá, no seu âmbito, o tratamento da questão religiosa.

Feito o diagnóstico, passa-se a defender, à luz do necessário debate acerca do que deve ser a laicidade, não só a possibilidade como a efetiva necessidade de participação da religião no âmbito da política, desde que respeitados determinados pressupostos.

Para isso, adota-se, como principal referencial teórico, o filósofo Jurgen Habermas e as ideias por ele defendidas especialmente a partir dos anos 2000, bem como escritos de Michael Sandel, professor da Universidade de Harvard.

\section{O DESENVOLVIMENTO DO ESTADO CONSTITUCIONAL DEMOCRÁTICO DE DIREITO DE CUNHO LIBERAL E SUA INFLUÊNCIA SOBRE A CONCEPÇÃO “RESTRITIVA” DO PAPEL DA RELIGIÃO NA ESFERA PÚBLICA}

Em texto intitulado "Religion in the public sphere", de 2006, o filósofo Jurgen Habermas se propõe a evidenciar a relação entre a concepção que desqualifica a participação do elemento religioso dentro da esfera 
pública e o desenvolvimento de um Estado constitucional de natureza liberal, no âmbito do qual a ética cidadã se encontra vinculada ao cumprimento de normas procedimentais que assegurem a participação de todos na construção das regras a que se subordinam.

Em um contexto de intensa interferência do religioso sobre o político no âmbito das guerras religiosas do início da modernidade, a superveniência do conceito de Estado constitucional de Direito se assentou, de início, sobre a defesa da existência de uma "razão comum" ou "razão natural", de elementos de índole contratual que a todos vinculassem, o que teria funcionado como a base epistemológica para o desenvolvimento de um Estado secular, passível de justificação independentemente da religião (HABERMAS, 2006).

No Estado Secular, a legitimação política adviria do viés democrático a ser obtido mediante o respeito a dois requisitos de natureza formal, exteriorizados na garantia da participação igualitária de todos os cidadãos no processo de produção das normas e na existência de um procedimento de deliberação presumidamente considerado apto a gerar resultados racionais aceitáveis.

Neste contexto, a tensão entre as diversas visões de mundo seria minimizada ou controlada pelas normas procedimentais a exigirem que "os cidadãos respeitem um aos outros enquanto membros livres e igualitários de uma comunidade política” (HABERMAS, 2006, p. 07).

No âmbito dessa concepção, a legitimação do jogo democrático exigiria que as Instituições políticas vertessem suas normas em linguagem a todos acessível, assentada em “razões públicas”, a impor a impossibilidade ou reserva à utilização, na esfera pública, de razões de índole privada, tais como as razões religiosas. Trata-se do que Habermas irá denominar, fazendo referência à Robert Audi, de "princípio da justificação secular", nos termos do qual um argumento só poderia ser justificado no âmbito da esfera pública acaso pautado em razões estritamente seculares.

Na vigência dessa ideia, o argumento religioso nunca poderia ser trazido para o âmbito da esfera pública, devendo ser mantido dentro dos estritos limites da esfera privada do indivíduo.

Essa visão liberal de neutralidade foi defendida, sob o ponto de vista filosófico, por John Rawls, em 1971, em seu livro denominado "Uma teoria da Justiça".

Na obra, Rawls propõe definir o que é Justiça a partir da formulação do questionamento acerca de quais princípios escolheríamos para insculpir em um contrato social e então reger as nossas vidas coletivas acaso estivéssemos todos em uma situação de equidade.

Reconhecendo que isto é impossível sob o ponto de vista prático, considerando-se que cada indivíduo é, de certa forma, condicionado por seus interesses, crenças morais, concepções religiosas distintas, classe social, raça e outros fatores, Rawls sugere que se faça uma experiência mental na qual todos os potenciais envolvidos na pactuação do contrato social participem da deliberação vestidos com um "véu da ignorância" que lhes impeça de vol.12, no. 01, Rio de Janeiro, 2019. pp.77-99 
saber quem realmente são. Só assim, desprovidos de informações referentes a nossa etnia, classe social, escolaridade, condição física, opiniões morais e religiosas, seríamos capazes de fazer uma escolha a partir de uma real posição de equidade, no âmbito da qual se tornaria possível escolher princípios gerais considerados justos (SANDEL, 2017).

Do contrato hipotético, Rawls acreditava que derivariam dois princípios gerais de justiça, exteriorizados nas ideias das liberdades básicas e de equidade social e econômica.

Em escritos posteriores, especialmente em 1993, ao escrever "Liberalismo Político", Rawls deixou claro aceitar a possibilidade de que indivíduos fossem incapazes de viver desprovidos de determinadas concepções religiosas ou morais, mas esse reconhecimento não o fez deixar de sustentar, sem flexibilização, a máxima de que "tais lealdades e apegos não deveriam ser a base da nossa identidade como cidadãos" (SANDEL, 2017, p. 209).

Nas palavras de Michael Sandel (2017, p. 209), em Rawls, "nas discussões sobre justiça e direitos, devemos deixar de lado nossas conviç̧óes morais e religiosas e discutir a partir de uma concepção política do indivíduo, independente de quaisquer lealdades, apegos ou concepções particulares de vida boa”.

A impossibilidade de que os cidadãos trouxessem aspectos morais e religiosos para a esfera pública se fundamentaria, segundo Rawls, na necessidade de que o debate público se efetivasse a partir da utilização da razão pública liberal, de modo a que o embate se desse entre argumentos a todos acessíveis (SANDEL, 2017).

Dessa forma, a justificativa para a profunda cisão entre o público e o considerado pela doutrina liberal como afeto ao âmbito do privado decorreria da necessidade de que fosse respeitado o "pluralismo sensato" no âmbito público, razão pela qual "a questão da neutralidade liberal nasce da necessidade de haver tolerância no que se refere às diversas concepções morais e religiosas" (SANDEL, 2017, p. 309).

Mas será que a concepção de neutralidade veiculada pelo Estado constitucional de Direito liberal de fato promove a tolerância? Qual o conceito de tolerância se está a defender?

\section{A INEFiCÁCIA DO CONCEITO SELETIVO - E TAMbÉm MORAL - DE TOLERÂNCIA LIBERAL}

Conforme exposto, no Estado constitucional de Direito de cunho liberal, a noção de tolerância se desenvolve como um instrumento de efetivação das liberdades básicas, a serem exercidas por um indivíduo esvaziado moralmente, na medida em que seus direitos, interesses e desejos não são mais estabelecidos a partir de uma perspectiva coletiva, mas sim subjetiva (GONDIM, 2011).

Esse afastamento do elemento moral do espaço público, no que Charles Colson e Nancy Pearcey (2006) denominam de "perda da autoridade moral da lei" gera profundas consequências, tais como a remoção 
das restrições ao comportamento individual e a perda da possibilidade do debate moral e da política em si mesma ${ }^{6}$, ao mesmo tempo em que reduz o governo à posição de condutor de procedimentos utilitários que impeçam que "as pessoas se choquem umas com as outras enquanto realizam suas coisas" (COLSON; PEARCEY, 2006, p.209).

O governo se transforma no que "o professor Michael Sandel, de Harvard, chama de uma república de procedimentos, que não rege nada além de procedimentos para ajudar as pessoas a conseguirem o que desejam" (COLSON; PEARCEY, 2006, p. 209), desprovido que se encontra da possibilidade de exercitar qualquer tarefa moral positiva.

Para além de todos estes problemas, uma questão central precisa ser enfrentada no que concerne à neutralidade liberal: a de que a neutralidade defendida pelo Estado liberal, por ele visualizada como um mecanismo garantidor da "tolerância”, na verdade é, em si mesma, uma opção moral que não a concretiza.

Em "Justiça - O que é fazer a coisa certa", Michael Sandel (2017) demonstra - adotando como exemplos as situações do aborto, da pesquisa com células embrionárias e do casamento com pessoas do mesmo sexo - como o argumento liberal supostamente neutro é, em verdade, tão somente uma escolha moral dentre todas as escolhas possíveis. A neutralidade que teria o propósito de garantir tolerância pelo não privilegiamento de nenhuma concepção moral ou religiosa termina exatamente por escolher uma delas, dentro de um mecanismo que de antemão já cerceia as concepções diversas?

Sandel (2017) desenvolve sua linha argumentativa adotando como exemplo a questão do casamento entre pessoas do mesmo sexo, para demonstrar que, no que concerne a esta matéria, há três posturas possíveis, do ponto de vista abstrato, a serem adotadas pelo Estado, quais sejam: 1) reconhecer apenas os casamentos entre um homem e uma mulher; 2) reconhecer igualmente os casamentos entre pessoas do mesmo sexo e do sexo oposto; 3) não reconhecer nenhum tipo de casamento e deixar esse papel para as associações privadas.

\footnotetext{
${ }^{6}$ Colson e Pearcey (2006, p. 209) afirmam que "Se a política trata apenas de quem consegue o que, então a política se torna um jogo interminável de gritarias, com uma briga infindável sobre as exigências pelos direitos - definidos, em última análise, por quem falar mais alto ou tiver mais votos. Os assuntos são definidos não pelos princípios, mas sim pelo poder".

${ }^{7}$ No âmbito do debate acerca do aborto, por exemplo, o autor assevera que: "Afirma-se que a questão do aborto deve ser resolvida com base na neutralidade do Estado e na liberdade de escolha, sem entrar na controvérsia moral ou religiosa. No entanto, esse argumento não se mostra convincente, porque, se for verdade que o feto em desenvolvimento é moralmente equivalente a uma criança, o aborto é moralmente equivalente ao infanticídio. E poucas pessoas concordariam com o governo se ele permitisse que os pais decidissem por conta própria se deveriam ou não matar seus filhos. Portanto, o argumento pró-escolha no caso do aborto não é realmente neutro quanto à questão moral e teológica implícita; ele assume implicitamente que os ensinamentos da Igreja Católica sobre o status moral do feto - que ele é um indivíduo desde o momento da concep̧ção - são falsos. (...) O argumento para permitir o aborto não é mais neutro que $o$ argumento para proibi-lo. Ambos os posicionamentos pressupõem uma resposta à controvérsia moral e religiosa implícita (SANDEL, 2017, p. 313).
} 
O autor então evidencia que a terceira possibilidade, embora puramente hipotética, pelo menos nos Estados Unidos, é a única que se amolda perfeitamente ao raciocínio liberal de neutralidade.

É que se o casamento deve ser considerado uma questão absolutamente privada, toda a discussão sobre casamento homossexual perderia o sentido, na medida em que não caberia ao Estado chancelar quaisquer espécies de casamento que fosse - heterossexual ou homossexual - devendo-se transferir, também para o âmbito da esfera de pactuação privada das partes envolvidas, as questões relativas a finanças, sustento dos filhos, guarda e correlatas. Essa opção é a que se amolda à neutralidade liberal porque "não exige que juízes e cidadãos entrem na controvérsia moral e religiosa sobre o propósito do casamento e a moralidade da homossexualidade (SANDEL, 2017, p. 317).

Em qualquer uma das outras duas opções, no entanto, não há como promover decisão sem que se adentre no temido terreno moral.

Para demonstrar sua tese, Sandel analisa o voto da juíza Margareth Marshall, presidente da Suprema Corte de Massachussets no caso Goodridge versus Departamento de Saúde Pública, relativo a casamento entre pessoas do mesmo sexo. Evidencia a linha argumentativa da juíza que, de início, deixa claro que a Corte não tomará partido nessa disputa e, logo em seguida, adota o argumento da neutralidade liberal para debater a questão à luz das ideias de autonomia e liberdade. No voto, sustenta-se que "a liberdade de escolher se casar e com quem se casar seria vã se o Estado pudesse tolher os direitos dos indivíduos de escolher livremente a pessoa com quem ela queira compartilhar um compromisso exclusivo" (SANDEL, 2017, p. 318).

Sandel então exterioriza a impropriedade da utilização dos conceitos de autonomia e de liberdade para fins de justificação do entendimento defendido. Ele argumenta que se o governo fosse de fato neutro quanto ao valor moral de todos os relacionamentos, não haveria como restringir a instituição do casamento a apenas duas pessoas, por exemplo, já que também se encontra inserida no âmbito da liberdade de escolher a própria possibilidade de desejar fazê-lo com mais de uma pessoa, argumento que poderia ser expandido para todo e qualquer arranjo.

Mas não é isso que ocorre no caso sob julgamento. Ao invés de desestatizar a instituição do casamento, retirando-lhe o selo do Estado, de modo a que cada indivíduo decida como gerir a sua vida, a juíza de Massachussets propõe uma ampliação interpretativa do conceito para incluir parceiros do mesmo sexo. A ampliação, assentada também em uma limitação a "duas pessoas", a negar validade à poligamia consensual, decorre da compreensão do casamento como uma "relação de comprometimento exclusiva e permanente entre dois parceiros", o que pressupõe - segundo Marshall - a adoção de uma concepção moral acerca de quais os propósitos do casamento e de sua função/importância social.

Nesse sentido, a verdadeira questão quando se trata do casamento homossexual não é "assegurar a vol.12, nº. 01, Rio de Janeiro, 2019. pp.77-99 
liberdade de escolha, mas definir se as uniões entre pessoas do mesmo sexo são dignas de respeito e reconhecimento por parte da comunidade, se elas cumprem o propósito da instituição social do casamento" (SANDEL, 2017, p. 319), de modo que "para decidir quem pode qualificar-se para o casamento, devemos raciocinar no sentido do propósito do casamento e se suas virtudes" (SANDEL, 2017, p. 321).

Essa exigência inexoravelmente nos conduz ao campo da moral e da religião, razão pela qual o argumento liberal a favor do casamento de pessoas do mesmo sexo, porquanto assentado numa compreensão preliminar acerca do valor moral das uniões desse tipo e de sua adequação ao propósito social da instituição do casamento, não é, nem de longe, neutra.

Ao se exteriorizar como uma tradição moral como qualquer outra, uma doutrina normativa que também se baseia em uma epistemologia moral e uma teoria da razão que constrói um mundo político dividido entre o público e o privado (GONDIM, 2011), o grande problema do liberalismo político é que efetua a opção por um conceito de moralidade construído de forma cerceadora, a partir da repressão, no espaço público, ao exercício da liberdade daqueles para quem a religião desempenha um papel de integralidade na vida, definindo não só seus relacionamentos interpessoais, mas também a própria forma como definem suas máximas concepções e decisões acerca de questões fundamentais relativas à justiça.

Para estas pessoas, é "sua concepção de justiça religiosamente mediada que lhes define o que é politicamente correto ou incorreto, significando que eles são incapazes de construir seus posicionamentos a partir de razões seculares" (HABERMAS, 2006, p.9).

Nesse sentido, Habermas (2006) afirma que adotada esta premissa - qual seja a de que a cosmovisão teísta de mundo pauta necessariamente a visão política do indivíduo, sendo-lhe impossível, sob o ponto de vista ontológico, dela se dissociar ao entrar na esfera pública - não há como o Estado liberal que expressamente protege essa forma de vida possa concomitantemente exigir de todos os seus cidadãos que eles justifiquem suas posições políticas de forma independente de suas convicções religiosas.

A inserção das convicções religiosas na esfera pública - a ser posteriormente destrinchada em espaço político e espaço institucional - é condição para o próprio exercício da tolerância que se almeja.

\section{A COSMOVISÃo PÓS-MODERNA COMO UM ELEMENTO RELEVANTE NA CRISE MORAL QUE AFETA A SOCIEDADE}

A não inserção do argumento moral e do religioso ${ }^{8}$ no âmbito da esfera pública, para além de baseada na

\footnotetext{
${ }^{8}$ Faz-se distinção entre argumento moral e religioso por se partir da premissa de que, para muitos, é possível defender a existência de normas morais não baseadas em concepções religiosas. Nesse sentido, artigo
} 
concepção liberal de neutralidade, é também decorrência da superveniência e consolidação da cosmovisão pósmoderna.

Entende-se por cosmovisão uma maneira específica de se conceber o mundo e as regras a partir das quais ele se organiza e funciona, ou ainda, nas palavras de James Sire (2004, p. 21),

um conjunto de pressuposições (hipóteses que podem ser verdadeiras, parcialmente verdadeiras ou inteiramente falsas) que sustentamos (consciente ou inconscientemente, consistente ou inconsistentemente) sobre a formação básica do nosso mundo.

Sire (2004) vê uma cosmovisão como o conjunto de respostas que um indivíduo adota para responder sete perguntas fundamentais correlacionadas à questão da existência (Qual a realidade primeira?, ou seja, de onde tudo deriva?), do ambiente que nos rodeia (Qual é a natureza da realidade externa?), de quem somos (O que é um ser humano? O que acontece quando uma pessoa morre?) e do que nos é possível conhecer e como (Por que é possível conhecer alguma coisa?; Como sabemos o que é certo e errado? Qual o significado da história humana?).

A partir das respostas dadas a estas sete perguntas fundamentais, James Sire identifica diversas cosmovisões, dentre elas a cosmovisão pós-moderna.

Citando Jean-François Lyotard, Sire (2004, p. 214) conceitua pós-modernismo ${ }^{9}$ como "a incredulidade voltada às metanarrativas". A cosmovisão pós-moderna seria caracterizada prioritariamente pelo relativismo conceitual, que passa a condicionar todos os aspectos da realidade pela crença de que nenhuma história, nenhuma narrativa, deve ter maior credibilidade e prevalência sobre qualquer outra.

A pós-modernidade pode então ser caracterizada como uma cosmovisão que promove um deslocamento do âmbito do ser para o do conhecer, conferindo especial importância ao elemento da linguagem, através da qual cada indivíduo formula suas próprias histórias. Na concepção pós-moderna, é possível encontrar

científico publicado na revista Trends in Cognitive Sciences, de autoria de Ilkka Pyysiäinen, da Universidade de Helsinki, na Finlândia, e Marc Hauser, dos Departamentos de Psicologia e Biologia Evolutiva Humana da Universidade Harvard, defende que "a cooperação é possível graças a um conjunto de mecanismos mentais que não são específicos da religião. Julgamentos morais dependem desses mecanismos e parecem operar independentemente da formação religiosa individual", de modo que "a religião "fornece apenas regras locais para casos muito específicos" de dilemas morais, como posições sobre o aborto ou a eutanásia. Já questões de caráter mais abstrato são definidas com base numa moralidade intuitiva que independe de religião". 0 artigo conclui que "a capacidade de distinguir entre certo e errado, aceitável e inaceitável, é intuitiva ao ser humano e independe da religião, apesar de ser moldada por ela em questões específicas". Disponível em: https://www.estadao.com.br/noticias/geral,moralidade-independe-de-religiao-diz-estudo,508375.

${ }^{9}$ Não há concordância quanto ao uso dos termos "pós-modernismo" e "pós-modernidade". Fredric Jameson (2011), crítico literário e teorista político norte-americano, sustenta existir diferença entre pós-modernismo enquanto estilo artístico e cultural surgido inicialmente na arquitetura e nela já abandonado pela superveniência da ideia de contemporaneidade e pós-modernidade enquanto estrutura. A pós-modernidade seria uma estrutura de capitalismo globalizado, relacionada às ideias de conexão global, capitalismo financeiro, redes de comunicação. Disponível em: https://www.fronteiras.com/videos/pos-modernismo-ou- 
significado nas diversas narrativas formuladas, mas não verdade, porque a verdade passa a ser "tudo aquilo que conseguimos com que nossos colegas (nossa comunidade) concorde. Se conseguimos fazê-los usar nossa linguagem assim, nossa história é tão verdadeira quanto qualquer história jamais contada” (SIRE, 2004, P. 221).

De acordo com Sire (2004), esse relativismo que admite como verdade toda e qualquer narrativa que seja objeto de concordância por parte da comunidade faz com que, no bojo do pós-modernismo, o bem social passe a ser visto como qualquer coisa que a sociedade assume como tal, produzindo-se, como consequência, um acentuado relativismo moral.

O homem pós-moderno é guiado pelo materialismo, hedonismo, relativismo, consumismo, nihilismo. É um homem plural, racional, secular.

Se "no passado, o estabelecimento de Deus e seu senhorio no universo resultavam no estabelecimento de verdades absolutas (...), agora não existem absolutos. Tudo é muito provisório, relativo, em vir-a-ser. Tudo é projeto, não existe nada acabado" (BARTH, 2007, p. 99) ${ }^{10}$.

A ética pós-moderna altera os valores morais, substituindo a ideia coletiva de "boa vida" pela de "bemestar" (BARTH, 2007).

Como alerta Bauman (2000, p. 09), "vivemos também uma época de privatização da utopia e dos modelos do bem (com os modelos de "boa vida" expulsos e eliminados do modelo de boa sociedade)" e o pior,

tendemos a nos orgulhar do que talvez devesse nos envergonhar: de viver numa época "pósideológica" ou "pós-utópica", de não nos preocuparmos com uma visão coerente de boa sociedade e de ter trocado a preocupação com o bem público pela liberdade de buscar satisfação pessoal (BAUMAN, 2000, p. 10).

Mas essa pós-modernidade é frágil, superficial, insustentável, líquida, e se depara continuamente com a necessidade de aprender a lidar com a existência de uma sociedade pós-secular que, a despeito de um ambiente cada vez mais secularizante, não tem como não lidar com a sobrevivência e fortalecimento de comunidades religiosas que dela participam (HABERMAS, 2013).

\section{A DEFESA DA EXISTÊNCIA DE UMA SOCIEDADE PÓS-SECULAR QUE PRECISA}

pos-modernidade. A despeito disso, na imensa maioria das vezes os termos "pós-modernismo" e "pósmodernidade" são utilizados como sinônimos.

10 Wilmar Luiz Barth (2007, p. 92) afirma que, para este homem, "sua ideologia é o pragmatismo. Sua norma de conduta é a vigência social, as vantagens que leva, o que está na moda. Sua ética se fundamenta na estatística, substituta da consciência. Sua moral, repleta de neutralidade, carente de compromisso e subjetividade, fica relegada à intimidade, sem se atrever a sair em público. Tudo é suave, ligeiro, sem riscos; somente faz algo com garantia. Em sua vida, não há rebeliões, pois sua moral se converteu numa ética de regras de urbanidade ou mera atitude estética. É frio, não acredita em quase nada, suas opiniões mudam rapidamente e deixou para trás os valores transcendentes. Busca o prazer e o bem-estar a qualquer custo, além do dinheiro. Para ele tudo é descartável, inclusive as pessoas. Passa por cima de tudo e de todos para buscar a fama, o sucesso, o triunfo. Vive unicamente para si, para seu prazer, sem restrições". 


\section{DIALOGAR COM O “RELIGIOSO”NA ESFERA PÚBLICA}

Em 2001, cerca de um mês após o atentado de 11 de setembro que fez ruir as torres gêmeas em Nova York, Jurgen Habermas recebeu o Prêmio da Paz concedido pela Associação dos Livreiros da Alemanha, ocasião na qual proferiu um discurso depois reproduzido no livro "Fé e Saber", no qual propõe uma reavaliação da tese tradicional da secularização, de modo a que se promova um questionamento do secularismo como visão de mundo.

Em "fé e saber" (2013, p. 05), Habermas exterioriza que a palavra "secularização", inicialmente concebida como "a transferência compulsória dos bens da Igreja para o poder público secular", passou a ser paulatinamente utilizada para designar o surgimento da modernidade cultural e social como um todo, de uma estrutura assentada na defesa da substituição dos modos de pensar e formas de vida religiosas por equivalentes racionais, tidos por superiores.

Em qualquer dos dois conceitos que se adote, há, segundo ele, um erro evidente, que é conceber a secularização como um jogo de soma zero que contrapõe de um lado as forças produtivas da ciência e da técnica, e de outro os poderes conservados da Igreja e da Religião, dentro de uma estrutura competitiva na qual a vitória de um dos participantes pressupõe a derrota do adversário.

Em sua visão, essa imagem não é adequada ao desenvolvimento de uma sociedade pós-secular, assim compreendida aquela que se vê compelida a se ajustar "à sobrevivência de comunidades religiosas em um ambiente cada vez mais secularizante" (HABERMAS, 2013, p. 06), na medida em que é impossível não constatar que "tão logo uma questão existencialmente relevante vá para a agenda política, os cidadãos - tanto crentes quanto não crentes - entram em colisão com suas convicções impregnadas de visões de mundo" (HABERMAS, 2013, p. 07) e é só "na medida que trabalham as agudas dissonâncias desse conflito público de opiniões" que têm a experiência do fato chocante do pluralismo que caracteriza o mundo pós-moderno (HABERMAS, 2013, p. 07).

Trabalhar as dissonâncias e não as desconsiderar.

Embora a secularização exija que haja, na construção da "razão pública", um igual distanciamento, por parte do Estado, em relação às fortes tradições e aos conteúdos impregnados em ambas as visões de mundo ${ }^{11}$, esta razão precisa permanecer aberta para a possibilidade de aprender com ambas as partes do conflito (HABERMAS, 2013).

Em "Fé e Saber" já há, para além da defesa da evidente necessidade da participação do elemento religioso

\footnotetext{
11 Torna-se interessante constatar como, nesta passagem, Habermas, ainda que não o faça expressamente, reconhece ser também a "não crença" uma visão de mundo por si mesma, na esteira da colocação de
} vol.12, no. 01, Rio de Janeiro, 2019. pp.77-99 
na esfera pública, o germinar da distinção entre esfera pública como espaço político e como espaço institucional, melhor desenvolvida em textos posteriores.

Em "Religion in the public sphere", Habermas defende explicitamente que não podemos derivar da característica da laicidade do Estado a imposição, aos cidadãos crentes, de que tenham que subverter suas concepções religiosas em "linguagem a todos acessível" ao adentrarem na esfera pública, sob pena de lhes impor um ônus mental e psicológico.

Assim, o Estado pode esperar de seus cidadãos crentes que eles compreendam que, na esfera institucional, exercita-se um princípio de neutralidade sobre diversas visões de mundo, mas não pode, de forma alguma, exigir ou mesmo esperar, ante, inclusive, a impossibilidade ontológica de que eles o façam, que dividam suas identidades em componentes públicos e privados ao participarem dos debates na arena pública (HABERMAS, 2006).

Percebe-se que Habermas se contrapõe de forma muito evidente à concepção do liberalismo político acerca da necessidade de dissociação entre o espaço público e o privado, ao defender que não se deve confundir a secularização do poder estatal com a secularização da sociedade.

Nesse sentido, a secularização estatal não conduz, como se tenta fazer crer, à perda da importância e significação da religião no âmbito de uma esfera pública política e na cultura da sociedade, que também é formada por cidadãos de fé, os quais podem e devem legitimamente influenciar, com suas concepções religiosas, a consciência social.

Na esfera pública como espaço político, é legítimo ao cidadão expressar publicamente e justificar suas concepções através da utilização, inclusive, da linguagem religiosa. Assim, "as comunidades religiosas podem pretender ter um lugar na vida das sociedades modernas, podem influir na formação da opinião e na vontade pública com contribuições relevantes" (HABERMAS, 2007, p. 05), podendo afirmarem-se na vida política das sociedades seculares como "comunidades de interpretação" (HABERMAS, 2007, p. 06).

A admissibilidade da expressão de argumentos religiosos no âmbito da esfera pública como espaço político advém não apenas do respeito necessário às concepções indissociáveis dos cidadãos crentes, que não estão dispostos ou até mesmo não podem separar, de forma tão absoluta, suas visões privadas de sua atuação pública, mas também e principalmente da impossibilidade de que a sociedade restrinja, de modo precipitado, a complexidade e diversidade das vozes que the compõem (HABERMAS, 2007).

O Estado democrático "não deveria dissuadir nem aos indivíduos nem às comunidades na hora de se expressarem voluntariamente porque não pode saber se não está a privar a própria sociedade de possíveis reservas

Michael Sandel, já mencionada neste artigo, de que há, na suposta neutralidade do liberalismo político, uma opção moral não reconhecida. 
de fundação de sentido e identidade" (HABERMAS, 2007, p. 06), na medida em que "especialmente em referência a âmbitos vulneráveis da convivência social, as tradições religiosas dispõem de força para articular instituições morais, sobretudo em atenção às formas mais sensíveis da convivência humana” (HABERMAS, 2007, p.06).

A imposição da dissociação - cuja própria possibilidade ontológica se questiona - entre o privado e o público, tão defendida pelo liberalismo político, gera uma perda para a sociedade secular na medida em que "a autoridade dos mandamentos divinos tem um eco na validade incondicional dos deveres morais que não podemos deixar de escutar" (HABERMAS, 2013, p. 17).

Mas Habermas diferencia a esfera pública como espaço político não institucionalizado da esfera pública política institucionalizada, deixando claro que há distinção entre o compromisso informal dos cidadãos na sociedade civil e na esfera pública e a atuação das instâncias institucionais, tais como parlamentos, tribunais, ministérios e autoridades administrativas.

Em "Religion in the public sphere" ele afirma categoricamente que "todo cidadão deve saber que apenas razões seculares contam perante o limiar institucional que divide a esfera pública informal dos parlamentos, cortes, ministérios e administração" (HABERMAS, 2006, p. 10).

Isso não significa, no entanto, o afastamento total do argumento religioso da esfera pública institucionalizada.

Após defender a plena possibilidade da participação da religião, em sua própria linguagem, na construção dos conceitos da coletividade na esfera política não institucional, Habermas sustentará que conceitos inicialmente religiosos poderão também invadir a esfera pública institucional, desde que se verifique a ocorrência, na fase préinstitucional, de sua tradução em linguagem moral geral a todos acessível.

A traduÇão DO ARgumento REligioso EM Linguagem Geral

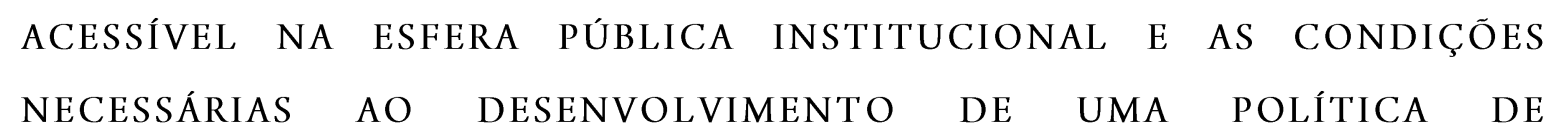
COMPROMETIMENTO MORAL

A tese defendida por Habermas acerca da possibilidade da inserção de argumentação originalmente religiosa na esfera pública institucionalizada se assenta na concepção de que a religião, assim como a razão secular, também pode ter pretensões de universalidade.

A partir da diferenciação entre a esfera pública informal e a institucionalizada, o autor sustenta que, embora não sujeitos a restrições no que concerne ao modo de sua expressão na esfera pública informal, 
argumentos religiosos devem se submeter ao requisito da tradução se desejarem obter a chance de serem levados em consideração nas agendas e negociações perante as instâncias políticas institucionais (HABERMAS, 2006).

Resta clara, portanto, a concepção de ser possível obter, a partir de concepções religiosas, linguagem universal passível de ser vertida em política/jurídica a todos acessível, o que decorre de seu entendimento, antes já evidenciado, de que "as tradições religiosas dispõem de força para articular instituições morais, sobretudo em atenção às formas mais sensíveis da convivência humana" (HABERMAS, 2007, p. 06).

Para fins de promover a tradução requerida, tornar-se-ia necessária a adoção de determinadas condições epistemológicas por parte dos cidadãos dotados de fé, exteriorizadas na necessidade de que a fé: 1) enfrente o elemento do pluralismo típico das sociedades pós-modernas; 2) reconheça a posição privilegiada em que as ciências se encontram para fins de determinação do que conhecemos e de como conhecemos, de modo a que as crenças científicas não sejam rechaçadas como algo que contradiz a fé; 3) reconheça a primazia do Estado laico e, assim, a primazia de que são dotadas as razões seculares na arena pública (HABERMAS, 2006).

É a partir da construção e do cumprimento dessas condições que se torna viável a inserção no elemento religiosa na esfera pública institucionalizada, sem que nela se sustentem, no entanto, dogmas de fé, verdades absolutas ou perspectivas absolutistas.

Essa concepção habermasiana acerca da necessidade de que haja uma tradução do argumento religioso também aparece, de certa forma, em Charles Colson e Nancy Pearcey (2006, p. 217) quando afirmam que

Embora as nossas crenças derivem das Escrituras, em uma sociedade pluralista nós também
devemos traduzi-las em termos que os não cristãos consigam entender. Por exemplo,
quando trabalhamos para mudar as leis do aborto, não devemos apenas apelar para a
revelação divina, mas também destacar que o dever mais fundamental do governo é
defender os que não têm quem os defenda. Quando nos opomos à legalização do suicídio
assistido e a eugenia, podemos observar que o próprio objetivo do governo é evitar o uso
privado da força letal. O governo exerce o poder da espada precisamente para que os
indivíduos não o façam. Precisamos lançar argumentos públicos e persuasivos que apelem à
razão eà evidência.

A grande questão é que, de acordo com Habermas, a tradução necessária à inserção do argumento religioso na esfera institucional não dependeria tão somente da atuação dos cidadãos dotados de fé, mas também de uma postura aberta e cooperativa por parte dos cidadãos seculares.

"O estabelecimento da fronteira controversa deve ser compreendido como uma tarefa cooperativa em que se exija dos dois lados aceitar também a perspectiva do outro” (HABERMAS, 2013, p. 16).

Referindo-se aos cidadãos seculares, ele afirma que eles "não devem chegar a conclusões, em questões deste tipo, antes de dar ouvidos à objeção dos oponentes que se sentem lesados em suas convicções religiosas", cabendo-lhes verificar "o que podem aprender com isso" (HABERMAS, 2013, p. 16).

Se, por outro lado, os cidadãos seculares compreendem as tradições religiosas como algo arcaico, típico 
das sociedades pré-modernas, surge um cenário no qual o direito de liberdade religiosa é visto como um mecanismo de proteção de algo que, na concepção daqueles, já deveria estar extinto, fazendo com que o princípio da separação entre Igreja e Estado se transforme, na prática, em um sentimento de indiferença para com tudo que advier do sagrado (HABERMAS, 2006)

Cidadãos que concebem a religião desta forma são obviamente incapazes de considerar com seriedade a potencialidade das contribuições dos argumentos religiosos para a construção de uma moralidade coletiva, o que faz com que a isenção da religião na esfera política, institucionalizada através de tradução em linguagem acessível, pressuponha, sob o ponto de vista cognitivo e epistemológico, também por parte destes, uma postura de abertura e de cooperação, no bojo da qual os cidadãos seculares avaliem suas discordâncias para com os cidadãos religiosos como desacordos razoavelmente esperados (HABERMAS, 2006).

Mas será que essas pressuposições cognitivas estabelecidas por Habermas existem na sociedade pósmoderna? Há espaço para a construção de uma moralidade a partir de uma tolerância como comprometimento, e não como indiferença?

Quando do julgamento da ADIN 4.439 ${ }^{12}$, em outubro de 2017, que tratou da possibilidade de ensino confessional nas escolas da rede pública brasileira, Amanda Mendonça ${ }^{13}$, coordenadora do Observatório da Laicidade na Educação (OLE), afirmou, em reportagem do site DCM, que

fomos muito críticos ao voto do relator, que apesar de ter defendido uma posição contrária ao modelo confessional, convocou argumentos que na verdade são contrários ao modelo da laicidade. Por exemplo, ele evocou o papel da religião na formação cidadã. A gente entende que a religião é um tema de foro privado, não cabe à escola pública essa função.

$\mathrm{Na}$ manifestação da entrevistada, parece fácil visualizar a inexistência das pressuposições cognitivas necessárias aos cidadãos seculares para que seja possível viabilizar a tradução do argumento religioso em linguagem geral acessível na esfera pública institucional.

A leitura da entrevista evidencia uma postura de fechamento em relação a este tipo de argumento, a partir

\begin{abstract}
${ }_{12}$ No julgamento da ADIN, o STF entendeu, por 6 votos a 5, pela possibilidade de ensino confessional nas escolas da rede pública, ao argumento de que a disponibilidade da opção

${ }^{13}$ Na mesma reportagem, mais a frente, a Coordenadora do OLE afirma que "Essa decisão não está descasada do contexto que estamos vivendo de retrocesso em relação a diversas pautas, não só na educação, e de avanço do campo religioso em direção a outros campos, principalmente do político e do educacional. Você combina isso com Escola Sem Partido, com a 'ideologia de gênero', com a proposta de escolas que separam meninos e meninas, que é o novo boom na educação privada. É um avanço muito rápido de setores conservadores que conseguem criar uma unidade que o campo progressista não consegue. É um momento muito complicado para o campo progressista como um todo. Há um crescimento de uma agenda conservadora, de uma retórica conservadora muito forte. Podemos citar a retirada de gênero dos planos de educação, o próprio movimento Escola Sem Partido". Assim, resta evidente seu descolamento do que considera uma "agenda conservadora" e aproximação do "campo progressista", a ratificar a crítica feita por Michael Sandel (2017) de que na neutralidade liberal há, sempre, ainda que não se queira admitir, a defesa de uma concepção moral. Disponível em: https://www.diariodocentrodomundo.com.br/o-brasil-eum-estado-laico-no-discurso-mas-nao-na-pratica-diz-pesquisadora-sobre-o-ensino-religioso/.
\end{abstract}


da qual se afasta, de antemão, a importância da religião na formação cidadã, enxergando-a como, nas palavras de Habermas (2006, p. 16), "como algo arcaico, típico das sociedades pré-modernas, (...) que já deveria estar extinto”. Em "Justiça - o que é fazer a coisa certa", Michael Sandel (2017, p. 330) sintetiza o problema, ao afirmar que

nas últimas décadas, passamos a achar que respeitar as conviç̧ões morais e religiosas de nossos compatriotas significa ignorá-las (pelo menos para propósitos políticos), não os perturbar e conduzir nossa vida pública - tanto quanto possível - sem fazer nenhuma referência a elas. Mas essa evasiva revela um respeito espúrio. Com frequência, significa suprimir as divergências morais em vez de evitálas. E isso pode provocar retrocessos e ressentimentos.

Ocorre que, não raras vezes, e de forma cada vez mais latente, essa atitude de conceber neutralidade como "exclusão" das concepções religiosas da esfera pública, de tolerância como "indiferença", tem se transformado em uma postura mais agressiva, a partir da qual se desqualifica o argumento religioso, não mais como algo que seja irrelevante para a esfera pública, mas como algo que, se nela inserido, a prejudica.

Exemplo deste acirramento, que nada mais é do que uma forma de intolerância, pode ser encontrado na manifestação da Comissão de Direitos Humanos do Estado do Colorado, nos Estados Unidos, proferida em 2012, quando de sua análise do caso "Masterpiece Cakeshop Ltd v. Colorado Civil Rights Comission et al", julgado recentemente pela Suprema Corte Americana.

No caso em questão, o Sr. Phillips, dono da Masterpiece Cakeshop, recusou-se, baseando-se em sua fé religiosa, a produzir, sob encomenda, um bolo de casamento para um casal homossexual que o procurou com esse fim. Inconformado, o casal apresentou uma queixa contra o dono da confeitaria perante a Comissão de Direitos Civis do Estado do Colorado, acusando-o de discriminação baseada em orientação sexual e, por conseguinte, de violação ao "Ato anti-discriminação" em vigor no Estado.

Em sua defesa, o Sr. Phillips afirmou não se negar a vender ao casal qualquer dos bolos e/ou doces expostos na loja, mas ponderou que criar um bolo de casamento especificamente para celebrar um evento que contraria frontalmente suas concepções religiosas significaria, de sua parte, um apoio pessoal e participação em algo que ele desaprova.

Salientou que, nos termos da Primeira Emenda à Constituição americana, referente à liberdade religiosa, entendia ter o direito de não ser obrigado a utilizar seus dons artísticos de modo a celebrar algo que viola suas convicções mais íntimas.

A Comissão de Direitos Civis do Estado do Colorado decidiu pela existência de conduta discriminatória, condenando-o a produzir o bolo nesta e em situações similares, entendimento que restou mantido pela Corte 
Estadual e foi, em 04 de junho de 2018, reformado pela Suprema Corte ${ }^{14}$.

No voto do relator, há transcrições de passagens das manifestações dos membros da Comissão de Direitos Civis do Estado do Colorado que indicam, de forma evidente, a existência de hostilidade por parte dos membros à visão religiosa do dono da confeitaria.

Nesse sentido, o voto reproduz manifestação de membro da Comissão para quem crenças religiosas não poderiam ser legitimamente trazidas para o âmbito da esfera pública ou do exercício de atividades econômicas, no bojo da qual se sustenta que o dono da confeitaria poderia acreditar no que quisesse, mas não podia agir, com base nas suas crenças, quando estivesse a desempenhar atividade econômica no Estado (SCOUT, 2018).

O juiz relator daquela Suprema Corte transcreve, em seguida, passagem ainda mais explícita na qual um membro da Comissão de Direitos Civis, fazendo analogia entre a recusa do Sr. Phillips e a utilização da religião para justificar a escravidão, o holocausto e outras situações ao longo da história, defende que "a utilização do argumento da liberdade religiosa é o pedaço mais desprezível da retórica a quem alguém pode recorrer de modo a utilizar sua religião como instrumento para ferir outros" (COURT, 2018, p. 13).

Guiado pelo propósito de assegurar o direito do casal de homossexuais de não serem discriminados em função de sua orientação sexual, o membro da Comissão de Direitos Civis do Colorado discrimina o Sr. Phillips em função de sua crença religiosa, deixando de considerá-la presumidamente como uma expressão sincera e respeitável de quem ele é para transformá-la em um mero instrumento retórico de opressão.

Assim, para combater a opressão da discriminação decorrente de orientação sexual, discrimina-se em função da fé, obtendo-se, em relação a outrem, a mesma opressão que se tentava evitar.

Essa hostilidade muito tem a ver com o adensamento pelo mundo do fundamentalismo religioso e do medo que estas visões mais radicais provocam ao levarem aos extremos a relação entre a religião e a política.

Em texto publicado em 2005, Joseph Hatzinger formula diversas perguntas

se o terrorismo é também alimentado por meio do fanatismo religioso (e ele o é), a religião é então um poder capaz de curar e salvar ou então, antes, um poder arcaico e perigoso que edifica falsos universalismos e, dessa forma, instiga a intolerância e o terror? A religião não deve, nesse caso, ser colocada sob a tutela da razão e ser cuidadosamente restringida?

(....) a gradual extinção da religião, sua superação, deve ser encarada como um progresso necessário da humanidade, a fim de que ela alcance o caminho da liberdade e da tolerância universal, ou não?

Em seguida, questiona também a confiabilidade da razão, ao argumentar que dela derivou, por exemplo,

a bomba atômica, bem como a criação e seleção de seres humanos em laboratório, tendente a transformar o

${ }^{14}$ Em Masterpiece Cakeshop Ltd v. Colorado Civil Rights Comission et al, o juiz Relator, juiz Kennedy, que estabeleceu a maioria, considerou que "Phillips tinha direito a um processo de decisão neutro que desse total e justa consideração a sua objeção religiosa como ele a apresentou, levando em consideração todas as circunstâncias envolvidas no caso". Disponível em: http://www.supremecourt.gov/opinions/17/pdf/16111_jel.pdf 
homem em produto.

Lança, por fim, sua questão central: "Portanto, agora a razão, inversamente, não deveria ser colocada sob supervisão? Mas por meio de quem ou de quê? Ou talvez a religião e a razão deveriam se demarcar mutuamente e cada uma deveria indicar os nichos da outra e a levar a seu caminho positivo?" (HATZINGER, 2005).

O hoje papa Bento XVI esclarece ser o caminho do diálogo a melhor solução, ao sustentar que a razão também deve ser lembrada em seus limites e aprender a disposição de ouvir as grandes tradições religiosas da humanidade porque "quando ela se emancipa completamente e coloca de lado essa disposição de ouvir, essa capacidade de correlação, ela se torna destruidora” (HATZINGER, 2005).

Há patologias na religião, não há dúvidas, "assim como há patologias da razão. (..) "Ambas são chamadas a se purificarem e curarem mutuamente, e é necessário que reconheçam o fato de que uma precisa da outra" (HATZINGER; SCHULLER, 2007, p. 89).

Nesse sentido, Bauman (2017, p. 323) salienta que nosso grande desafio é "imaginar uma política que leve a sério as questões morais e espirituais, mas que as aplique a interesses econômicos e cívicos, e não apenas a sexo e aborto".

Assim, "ao invés de evitar as conviç̧ões morais e religiosas que nossos concidadãos levam para a vida pública, deveríamos nos dedicar a elas mais diretamente - às vezes desafiando-as e contestando-as, às vezes ouvindo e aprendendo com elas" (SANDEL, 2017, p. 330).

\section{CONCLUSÃO}

No livro "Em busca da política", de 2000, Symunt Bauman chama a atenção para o fato de que o intenso aumento da liberdade individual na sociedade pós-moderna fez surgir um cenário no qual se torna cada vez mais complexo construir pontes entre o privado e o público, bem como discernir dentro dos problemas privados o que viria a ser público.

No entanto, não há como discordar que uma sociedade que se pretenda justa precisa construir coletivamente o que entende por justiça, qual o seu conceito de "vida boa", e então pautar seu discurso político a partir desta definição.

Sendo esta sociedade também democrática, torna-se necessário que ela viabilize a participação, dentro da esfera pública, não apenas de seus cidadãos desprovidos de concepções religiosas, mas também da parcela de seus cidadãos que têm na fé o fio condutor de suas próprias existências, para os quais se torna ontologicamente impossível distinguir entre a esfera privada e a atuação política, tal como desejado pelo liberalismo político na intransigente defesa da neutralidade. 
Inserida neste contexto, a visão de Habermas adquire relevância ao defender a plena possibilidade da participação do argumento religioso, vertido na própria linguagem religiosa, na esfera pública informal, ou seja, não institucionalizada, bem como também a possibilidade de inserção deste argumento na esfera pública institucionalizada, desde que traduzido em linguagem acessível a todos.

Nele, torna-se possível visualizar-se: 1) a defesa da superação da absoluta distinção entre o privado e público; 2) o reconhecimento da impossibilidade ontológica de que o cidadão dotado de fé cumpra os requisitos de dissociação que thes foram impostos pelo liberalismo político; 3) a premissa da impossibilidade de que uma sociedade que se pretenda democrática restrinja, de modo precipitado, a complexidade e diversidade das vozes que lhe compõem; 4) a exteriorização da necessidade que haja, por parte dos cidadãos não crentes, mudança de mentalidade, de modo a reconhecerem que há nas tradições religiosas importantes recursos para a criação de "sentido" no âmbito do político, ante sua ampla aptidão para articular instituições morais, sobretudo em atenção às formas mais sensíveis da convivência humana.

Como consequência, surge a defesa de que a neutralidade ideológica do poder do Estado que garante as mesmas liberdades éticas a todos os cidadãos - cidadãos crentes obviamente incluídos - impõe a substituição, no âmbito do conceito de laicidade, de neutralidade como exclusão para neutralidade como imparcialidade inclusiva.

Em um Estado que se pretenda democrático, não há como estabelecer um cenário de respeito mútuo forte entre os atores da esfera pública sem que haja, de início, como condição, um maior comprometimento público com nossas divergências morais.

É através do enfrentamento público destas divergências, sempre voltado a tentativa de reduzi-las via construção de "consensos possíveis", e não mediante sua supressão da esfera pública, que seremos capazes de avançar democraticamente, reduzindo retrocessos e ressentimentos.

\section{SECULARIZATION, SECULARITY AND COSMOVISIONS IN CONFLICT: THE SPACE OF RELIGION IN THE PUBLIC SPHERE}

\section{Abstract}

This article aims to discuss the space of religion in the public sphere within a democratically inclined Rule of law. The text highlights how the development of the liberal constitutional state influenced the supervenience of a restrictive conception of the role of religion in the public sphere, creating a concept of tolerance as "indifference", based on absolute dissociation between public and private space. It correlates to the strengthening of the view that removes the religious element from public debate and, especially, from the institutional sphere of the state, to the 
postmodern worldview. Stemming from the distinction between state and society, it defends the inefficiency of the concept of liberal tolerance to handle a society characterized as "post-secular" in demanding that the state engage with the religious element. Based on texts by Jurgen Habermas and Michael Sandel, the article defends not only the possibility but also the effective need for, as long as determined epistemological postulates are followed, the religious argument to be incorporated to the political and even institutional debate. It defends the necessity of substituting the idea of neutrality as "indifference" for neutrality as "inclusion", as more able to facilitate the appearance of a social and legal scenario of greater commitment to moral divergences and greater democratic density.

Keywords: Religion.Secularization. Secularity. Public sphere. Tolerance. Democracy.

\section{REFERÊNCIAS}

BARTH, Wilmar Luís. O homem pós-moderno, religião e ética. Teocomunicação, Porto Alegre, v. 37, n. 155, p. 89-108, mar. 2007.

BAUMAN, Zygmunt. Em busca da política. Rio de Janeiro: Jorge Zahar Ed, 2000.

BRASIL. STF. (06 de 06 de 2018). ADIN 3.510; Relator: Ministro Ayres Britto. DJ: 29/05/2008. Fonte: STF: http://www.stf.jus.br/portal/geral/verPdfPaginado.asp?id=61 1723\&tipo=AC\&descricao=Inteiro\%20Teor\%20 ADI\%20/\%203510. Acesso em: 03 jun 2018.

BRASIL. STF. (06 de 06 de 2018). ADPF No 54. Relator: Ministro Marco Aurélio Mello. DJ: 12/04/2012. Fonte: STF: www.stf.jus.br/arquivo/cms/noticianoticiastf/anexo/adpf54.pdf. Acesso em: 03 jun 2018.

COLSO, Charles; PEARCEY, Nancy. O cristão na Cultura de hoje. Rio de Janeiro: CPAD, 2006.

D 'SOUZA, Dinesh. A verdade sobre o cristianismo. Por que a religião criada por Jesus é moderna, fascinante e inquestionável. Rio de Janeiro: Thomas Nelson Brasil, 2008.

GONDIM, Larissa Cristine Daniel. A política da tolerância e o reconhecimento da diferença. 2011. 147 f. _vol.12, no. 01, Rio de Janeiro, 2019. pp.77-99 
Dissertação (Mestrado em Filosofia) - Universidade Federal da Paraíba, João Pessoa, 2011.

GRACHER, KHERIAN. Relativismo cultural em pauta. Março/2014. Site Universo racionalista. Disponível em: https://universoracionalista.org/relativismo-cultural-em-pauta/. Acesso em: 06 jun. 2018.

HABERMAS, Jurgen. Fé e Saber. São Paulo: Editora Unesp, 2013.

La voz pública de La religion. Respuesta a la tesis de Paolo Flores d Arcais. Claves de Razón Prática, 2007, n. 180. Disponível em: www.elboomeran.com/upload/ficheros/.../claveshabermas.pdf

Religion in the public sphere. In: European Jounal of Philosophy. Volume 14, 2006, p 1-25. Disponível em: https:// doi.org/10.1111/j.1468-0378.2006.00241.x.

HATZINGER, Joseph. O homem desceu até o fundo do poder, até a fonte de sua própria existência. Artigo de opinião. 2005. Disponível em: https://wwwl.folha.uol.com.br/fsp/mais/fs2404200509.htm. Acesso em: 07 jun 2018.

JAMESON, Fredric. Pós-modernismo ou pós-modernidade? 2011. (3m33s). Disponível em: https://www.fronteiras.com/videos/pos-modernismo-ou-pos-modernidade. Acesso em: 06 Jun 2018.

MATLARY, Janne Haaland. Derechos humanos depredados. Hacia una ditadura del relativismo. Madrid: Ediciones Cristiandad, 2008.

MORALIDADE independe de religião, diz estudo. 2010. Disponível em: https://www.estadao.com.br/noticias/geral,moralidade-independe-de-religiao-diz-estudo,508375. Acesso em: 06 jun 2018.

O Brasil é um Estado laico no discurso, mas não na prática”, diz pesquisadora sobre o ensino religioso. Artigo de opinião. Disponível em: https://www.diariodocentrodomundo.com.br/o-brasil-e-um-estado-laico-no-discursomas-nao-na-pratica-diz-pesquisadora-sobre-o-ensino-religioso/. Acesso em: 07 jun 2018.

PONDÉ, Luiz Felipe. Invenção do Contemporâneo: Diagnóstico de Zygmunt Bauman para a Pós-Modernidade - In Café Filosófico. Campinas: CPFL Cultura, 2011. Disponível em < https://www.youtube.com/watch?v=qxtRVyMphk >. Acesso em: 03 jun 2018. 
SANDEL, Michael J. Justiça - O que é fazer a coisa certa. Rio de Janeiro: Civilização brasileira, 2017.

SCHÜLLER, Florian (Org.). Dialética da secularização: sobre razão e religião. São Paulo: Idéias \& Letras, 2007.

SIRE, James W. O universo ao lado. São Paulo: Editora Hagnos, 2004.

USA. Supreme Court of United States of America. (2018). Masterpiece Cakeshop Ltd v. Colorado Civil Rights Comission et al. Disponível em: http://www.supremecourt.gov/opinions/17/pdf/16-111_j4el.pdf. Acesso em: 11 jun 2018.

Trabalho enviado em 18 de julho de 2018

Aceito em 12 de janeiro de 2019 